\title{
GRANULATED BRAN'S THERMOPHYSICAL CHARACTERISTICS AND DRYING MATHEMATICAL MODELS
}

\author{
O. Shapovalenko, O. Yevtushenko, V. Pochep \\ National University of Food Technologies
}

\begin{tabular}{l} 
Key words: \\
Thermophysical \\
characteristics \\
Approximation equation \\
Bran drying \\
\hline \multicolumn{1}{c}{ Article history: } \\
Received 18.05.2018 \\
Received in revised form \\
04.06 .2018 \\
Accepted 19.06 .2018 \\
\hline
\end{tabular}

Corresponding author:

O. Yevtushenko

E-mail:

yevtushenko.o.o@

gmail.com

\begin{abstract}
The article presents information about determination of granulated wheat bran's thermophysical characteristics (thermal conductivity, heat capacity and temperature conductivity) and mathematical models of their drying.

It is determined that granulated wheat bran's thermal conductivity and heat capacity grow from 0,862 to $1,016 \mathrm{~W} /(\mathrm{m} \cdot \mathrm{K})$ and from 661 to $1215 \mathrm{~kJ} /(\mathrm{kg} \cdot \mathrm{K})$ with increasing temperature from 20 to $60^{\circ} \mathrm{C}$ respectively (humidity content of $10.0 \%$ ). The same dynamics is observed for humidity of $15.0 \%$ and $20.0 \%$. However, the temperature conductivity of granular wheat bran decreases with increasing temperature from $20 \cdot 10^{-7}$ to $12,9 \cdot 10^{-7} \mathrm{~m}^{2} / \mathrm{s}$ at a humidity of $10.0 \%$, which corresponds to the description of capillary-porous bodies thermophysical characteristics.

There are diagrams and curves of drying of granules and drying of speed. For them, it was found that granules' humidity content decrease by $0.6 \ldots 1.2 \%$ when cooled for $10 \mathrm{minu}-$ tes at an air temperature of $10 \ldots 20^{\circ} \mathrm{C}$ and its speed of $0.6 \mathrm{~m} / \mathrm{s}$, which does not corresponds to the requirements of normative documents. Therefore, it is expedient to use a coolant with a temperature of $70 \ldots 80^{\circ} \mathrm{C}$ when drying granules, using water as a softener.

An equation of linear, logarithmic, polynomial, degreesial and exponential approximation for the corresponding granule drying curves is shown in the article. Polynomial equations had the greatest approximative reliability in the mathematical description of drying curves and speed of drying. The following quadratic polynomials were determined for the drying curves with certainty about $99 \%$ :

$$
\begin{aligned}
& y=0.0309 x^{2} 0.3434 x+1.105\left(d=7.7 \mathrm{~mm}, t=10^{\circ} \mathrm{C}\right), \\
& y=0.0329 x^{2}-0.3657 x+1.19\left(d=7.7 \mathrm{~mm}, t=20^{\circ} \mathrm{C}\right), \\
& y=0.0493 x^{2}-0.5027 x+1.372\left(d=9.7 \mathrm{~mm}, t=10^{\circ} \mathrm{C}\right), \\
& y=0.0479 x^{2}-0.5024 x+1.436\left(d=9.7 \mathrm{~mm}, t=20^{\circ} \mathrm{C}\right) .
\end{aligned}
$$
\end{abstract}

Estimated heat energy consumption for cooling pellets after press is $13508.5 \mathrm{MJ} /$ ton, and for their manufacture $94.5 \mathrm{MJ} /$ ton.

DOI: $10.24263 / 2225-2924-2018-24-3-25$ 


\title{
ТЕПЛОФІЗИЧНІ ХАРАКТЕРИСТИКИ ГРАНУЛЬОВАНИХ ВИСІВОК I МАТЕМАТИЧНІ МОДЕЛІ СУШІННЯ
}

\author{
О.І. Шаповаленко, О.О. Євтушенко, В.А. Почеп \\ Національний університет харчових технологій
}

У статті визначено теплофізичні характеристики (теплопровідності, теплоємності й температуропровідності) гранульованих пшеничних висівок і розроблено математичні моделі їх сушіння.

3'ясовано, що теплопровідність $i$ теплоємність зразка гранульованих пшеничних висівок зростає при збільшенні температури з 20 до $60^{\circ} \mathrm{C}$ від 0,862 до 1,016 Bm/(м.K) та з 661 до $1215 \kappa Д ж /(к 2 \cdot K)$ відповідно при вологості 10,0\%. Така ж динаміка спостерігається і для вологості 15,0\% та 20,0\%. Однак температуропровідність гранульованих пшеничних висівок знижується із зростанням температури з $20 \cdot 10^{-7}$ до $12,9 \cdot 10^{-7} \mathrm{M}^{2} / \mathrm{c}$ при вологості 10,0\%, ще відповідає опису ТФХ капілярно-пористих тіл.

Представлені графіки кривих сушіння гранул і кривих швидкості їх сушіння. За ними встановлено, щчо зниження вологовмісту гранул при їх охолодженні протягом 10 хв при температурі повітря $10 \ldots 20^{\circ} \mathrm{C}$ і його швидкості 0,6 м/с становить 0,6...1,2\%, шо не відповідає вимогам нормативних документів. Тому доцільним є використання теплоносія 3 температурою $70 \ldots 80^{\circ} \mathrm{C}$ при сушінні гранул, виготовлених з використанням як пластифікатора питної води.

Наведено рівняння, які відповідали лінійній, логарифмічній, поліноміальній, степеневій та експоненціальній апроксимації для відповідних кривих сушіння гранул. При розрахунку рівнянь математичного опису кривих сушіння $i$ кривих швидкості сушіння гранул найбільшу апроксиматичну достовірність мали поліноміальні рівняння. 3 достовірнітю близько 99\% визначено такі квадратичні поліноми для кривих швидкості сушіння: $y=0,0309 x^{2}-0,3434 x+1,105$ $\left(d=7,7 \mathrm{MM}, t=10^{\circ} \mathrm{C}\right), y=0,0329 x^{2}-0,3657 x+1,19\left(d=7,7 \mathrm{MM}, t=20^{\circ} \mathrm{C}\right)$, $y=0,0493 x^{2}-0,5027 x+1,372\left(d=9,7 \mathrm{Mu}, t=10^{\circ} \mathrm{C}\right), \quad y=0,0479 x^{2}-$ $-0,5024 x+1,436\left(d=9,7 \mathrm{Mn}, t=20^{\circ} \mathrm{C}\right)$.

Також наводено розрахунок витрати теплової енергії на охолодження гранул після преса, щөо становив 13 508,5 МДж/т гранул, а на їх виготовлення 94,5 МДж/т гранул.

Ключові слова: теплофізичні характеристики, рівняння апроксимачії, сушіння висівок.

Постановка проблеми. Для обгрунтування раціональних режимів тепломасообмінних процесів, що відбуваються при нагріванні та сушінні продуктів переробки зерна, визначають теплофізичні характеристики (ТФХ) [1].

Основними теплофізичними характеристиками є:

- теплопровідність $(\lambda)$, яка характеризує здатність тіла проводити тепло і чисельно дорівнює кількості тепла, що проходить в одиницю часу через 
одиницю площі ізотермічної поверхні при температурному градієнті $\Delta \mathrm{T}$, що дорівнює одиниці;

- температуропровідність $(\alpha)$, яка характеризує швидкість вирівнювання температури в різних точках температурного поля тіла $\alpha=\lambda /(\rho \cdot c)$ [2].

- питома теплоємність $(\rho \cdot c)$ продукту $є$ складною функцією його вологості і температури, де $\rho$ - щільність, а $c$ - питома теплоємність.

Зерно та продукти його переробки мають дисперсну структуру, яка відрізняється за фракціями залежно від розміру часток, між якими знаходиться повітря або інші газоподібні компоненти. Тому в дисперсних матеріалах можна визначити лише ефективні значення ТФХ. Для дисперсних видів сировини $\mathrm{i}$ готової продукції різниця в значеннях ТФХ, які отримані різними дослідниками і різними методами, може досягати десятків відсотків. Це пов'язано 3 тим, що на значення ТФХ впливає походження і природа речовини, оскільки розміри й розташування квазічасток на молекулярному рівні мають різний характер для одного і того ж виду зразків, але виготовлених в різних умовах.

Крім того, теплопровідність, температуропровідність і питома теплоємність дисперсних продуктів залежить від їх температури, вологості та характеру зв'язку вологи з матеріалом, крупності часток, об'ємної маси, густини, пористості тощо [2]. Тому визначення ТФХ $є$ актуальним питанням для визначення показників якості кожної нової партії продукції.

Питаннями водо- чи паротеплової обробки, сушіння й охолодження вологих продуктів і матеріалів, у тому числі і гранульованих, а також факторами, які впливають на процес ВТО, інтенсивність сушіння та охолодження продуктів і емпіричними рівняннями для проведення розрахунків щодо режимів зневоднення різних матеріалів, аналізом їх кривих сушіння і швидкості сушіння займались як вітчизняні, так і зарубіжні дослідники,.

Методи розрахунку були перенесенні на зневоднення гранульованих продуктів, які отримані як при вологому способі гранулювання, так і при сухому методі.

Для інтенсифікації процесу сушіння необхідним є додаткове введення в систему енергії, яка витрачається на підтримання перехідних явищ. Перетворення форм енергії в інші і в теплову відбувається без втрат, за винятком теплової енергії, яка згідно з другим законом термодинаміки перетворюється в інші форми лише частково. Оскільки теплова енергія на сьогодні залишається основним першоджерелом енергії, то слід дотримуватися мінімальних iï втрат, викликаних енергетичними перетвореннями [3]. При цьому найбільша частка втрат теплоти зерносушильних агрегатів припадає на відпрацьовані робочі гази і може перевищувати витрати фазових перетворень вологи в сировині, яка сушиться [4].

Однак при проведенні процесу зневоднення будь-якого матеріалу неможливо передбачити характер його проходження, якщо при цьому відбувається змінення методу, режиму або виду продукту. Якщо відбувається змінення хоча б одного з перелічених вище факторів, то виникає необхідність у проведенні складних і тривалих дослідів. Існуюча методологічна база узагальнення кривих сушіння дає змогу використовувати їх при проведенні 
дослідів зі зневоднення й охолодження гранульованих матеріалів, хоча при цьому в повній мірі не використовується весь потенціал програмного комп’ютерного забезпечення.

Мета дослідження: визначити ТФХ висівок пшеничних гранульованих, виготовлених у виробничих умовах млинзаводу на грануляторі з діаметром отворів матриці 7,7 та 9,7 мм, дослідити зміну показника достовірності апроксимації $\left(R^{2}\right)$ для різних рівнянь, які описують криві сушіння та швидкості сушіння цих гранул, а також розрахувати витрати теплової енергії на технологічній лінії гранулювання при використанні пропарювання продукту.

Матеріали і методи. ТФХ гранульованих висівок як дисперсних матеріалів можна визначити за допомогою спеціального обладнання, принцип дії якого заснований на комплексному теплометричному способі колориметра 3 направленим транзитом тепла.

У лабораторних умовах для проведення досліджень гранули діаметром 4,0 мм, які виготовляли на грануляторі італійського виробництва PSI Shultz продуктивністю 400 кг/год, підсушували до вологості 10,0\% або зволожували водою до $20,0 \%$ (на загальну масу). Температуру зразка гранульованих висівок змінювали $320^{\circ} \mathrm{C}$ до $60^{\circ} \mathrm{C}$.

Дослідження 3 визначення ТФХ гранульованих пшеничних висівок проводили на лабораторній установці кафедри теплотехніки НУХТ. На експериментальній установці теплопровідність $(\lambda)$ визначали за методом пласкої пластини. Включення термостатів на різні температури викликало транзит тепла крізь зразок матеріалу від нагрівача до холодильника, про що сигналізувала рівність потоків тепла, які входили в зразок і виходитли із зразка матеріалу.

Таким же чином виконується ряд перехідних режимів і за їх результатами

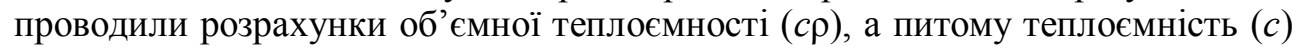
розраховували за формулою:

$$
c=\frac{c \rho}{\rho}, \text { Дж/(кг·К), }
$$

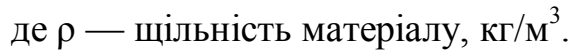

Температуропровідність $(\alpha)$ зразка матеріалу розраховували для середньої температури перехідного режиму за формулою:

$$
\alpha=\lambda_{1}+\frac{\lambda_{2}}{2 c \rho}, \mathrm{m}^{2} / \mathrm{c}
$$

Дослідження із сушіння гранульованих висівок при їх охолоджені проводили 3 метою визначення можливостей зневоднення продукту, виготовленому з використанням води як пластифікатора процесу.

Для побудови кривих сушіння гранул можна використовувати узагальнене рівняння кінетики сушіння або узагальнену криву сушіння гранульованих комбікормів і висівок.

При проведенні досліджень з кінетики сушіння гранул при їх охолодженні використовували узагальнену криву сушіння і визначили координати вологовмісту при температурі агента сушіння від 10 до $20^{\circ} \mathrm{C}$ при експозиції процесу 10 хв та будували криві сушіння та швидкості сушіння гранульованих висівок при різних значеннях часу (рис. 1,2 ). Подальші визначення математичних 
формул, які описують ці процеси, були здійснені за допомогою побудови ліній тренду засобами Microsoft Office Excel.

Для гранулювання кормової суміші на основі висівок з використанням як пластифікатора пари розрахунок витрати теплової енергії на різних етапах технологічного процесу проводили відповідно до «Інструкції № 9-1-85...» [5].

Визначення витрат теплової енергії при гранулюванні на 1 тонну висівок визначали за формулою (3):

$$
q_{\mathrm{rp}}=K_{\mathrm{T}}\left(0,384+\frac{0,616 W}{100}\right) \cdot\left(t_{2}-t_{1}\right), \text { тис. ккал / т висівок, }
$$

де $K_{\mathrm{T}}=1,2-$ коефіцієнт, який враховує теплові втрати; $W-$ вологість висівок до преса гранулятора, \%; $t_{1}$ i $t_{2}$ - температура висівок до і після пропарювання (кондиціонування) в змішувачі преса гранулятора, ${ }^{\circ} \mathrm{C}$.

Витрати теплової енергії на підігрів зовнішнього повітря до $5{ }^{\circ} \mathrm{C}$ при охолодженні 1 тонни гранульованих висівок визначали за формулою (4):

$$
q_{\mathrm{ox}}=\frac{c \cdot\left(5-t_{\text {cер.оп }}\right) \cdot L}{P}, \text { тис. ккал / т гранул, }
$$

де $c$ - теплоємність зовнішнього повітря, ккал/( $\left.{ }^{3} \cdot{ }^{\circ} \mathrm{C}\right) ; 5-$ температура пі-

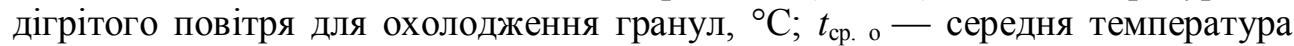
зовнішнього повітря за опалювальний період, ${ }^{\circ} \mathrm{C} ; L-$ витрати повітря на охолодження гранул, $\mathrm{m}^{3} /$ год; $P$ - продуктивність охолоджувача, т/год.

Результати і обговорення. Після обробки експериментальних даних отримали теплофізичніхарактеристики (ТФХ) гранул, які наведені в табл. 1.

\begin{tabular}{|c|c|c|c|c|}
\hline $\begin{array}{c}\text { Вологість, } \\
\%\end{array}$ & $\begin{array}{l}\text { Температра, } \\
{ }^{\circ} \mathrm{C}\end{array}$ & $\begin{array}{c}\text { Теплопровідність, } \\
\text { Вт/(м·К) }\end{array}$ & $\begin{array}{l}\text { Теплоємність, } \\
\text { кДж/(кг·К) }\end{array}$ & $\begin{array}{c}\text { Температуро-провідність, } \\
\alpha \cdot 10^{-7}, \mathrm{M}^{2} / \mathrm{c}\end{array}$ \\
\hline \multirow{4}{*}{10,0} & 20 & 0,862 & 661 & 20 \\
\hline & 30 & 0,901 & 740 & 18,7 \\
\hline & 40 & 0,939 & 978 & 14,8 \\
\hline & 60 & 1,016 & 1215 & 12,9 \\
\hline \multirow{4}{*}{15,0} & 20 & 1,083 & 816 & 20,4 \\
\hline & 30 & 1,149 & 935 & 18,9 \\
\hline & 40 & 1,214 & 1133 & 16,5 \\
\hline & 60 & 1,346 & 1410 & 14,7 \\
\hline \multirow{4}{*}{20,0} & 20 & 1,304 & 972 & 20,6 \\
\hline & 30 & 1,397 & 1130 & 19,0 \\
\hline & 40 & 1,490 & 1289 & 17,8 \\
\hline & 60 & 1,676 & 1606 & 16,0 \\
\hline
\end{tabular}

\section{Таблиия 1. Теплофізичні характеристики гранульованих пшеничних висівок}

Аналізуючи результати, наведені в табл. 1, можна відзначити, що із збільшенням температури з 20 до $60^{\circ} \mathrm{C}$ для зразків гранульованих пшеничних висівок при постійній їх вологості маємо такі закономірності для ТФХ:

- теплопровідність зростає від 0,862 до $1,016 \mathrm{BT} /($ м $\cdot$ К) при вологості $10,0 \%$; від 1,083 до 1,346 Вт/(м · К) — при вологості 15,0\%; від 1,304 до 1,676 Вт/(м · К) при вологості $20,0 \%$.

- теплоємність зразка гранульованих пшеничних висівок зростає з 661 до 1215 кДж/(кг · К) при вологості 10,0\%; 3816 до 1410 кДж/(кг · К) — при 
вологості 15,0\%; 3972 до 1606 кДж/(кг · К) — при вологості 20,0\% за такої ж величини збільшення температури з 20 до $60^{\circ} \mathrm{C}$.

- температуропровідність гранульованих пшеничних висівок знижується із зростанням температури $320 \cdot 10^{-7}$ до $12,9 \cdot 10^{-7} \mathrm{~m}^{2} / \mathrm{c}$ при вологості $10,0 \%, 3$ $20,4 \cdot 10^{-7}$ до $14,7 \cdot 10^{-7} \mathrm{M}^{2} / \mathrm{c}$ — при вологості $15,0 \%$, з $20,6 \cdot 10^{-7}$ до $16,0 \cdot 10^{-7} \mathrm{~m}^{2} / \mathrm{c}$ при вологості $20,0 \%$.

Криві сушіння гранульованих пшеничних висівок при охолодженні залежно від зміни їхнього діаметра з 7,7 до 9,7 мм та при температурі повітря 10 та $20^{\circ} \mathrm{C}$ показано на рис. 1 .

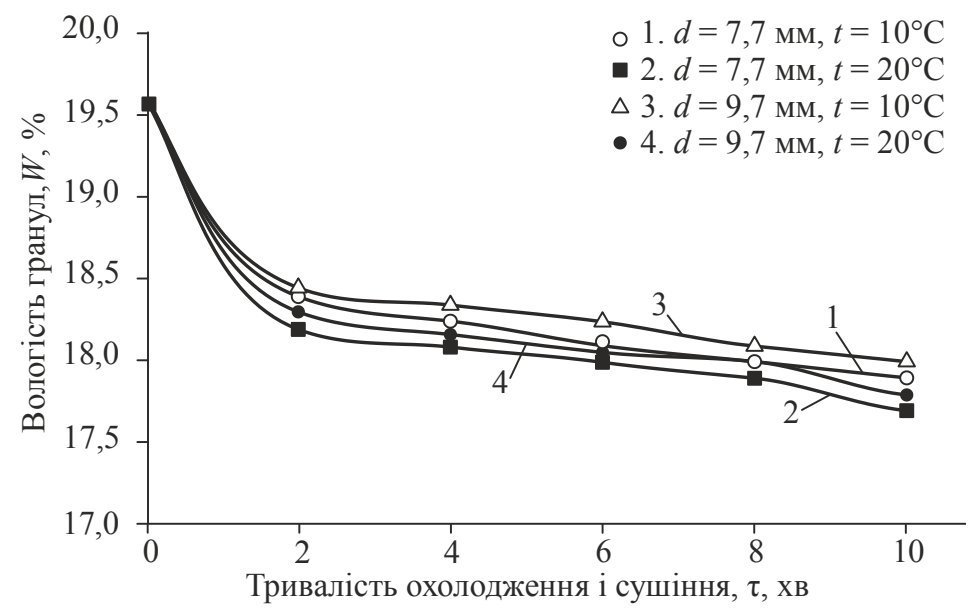

Рис. 1. Криві сушіння гранульованих пшеничних висівок при їх охолодженні $(V=0,6 \mathrm{~m} / \mathrm{c})$

За допомогою програмного забезпечення для відповідних кривих сушіння гранул (рис. 1) були визначені рівняння, які відповідали лінійній, логарифмічній, поліноміальній, степеневій та експоненціальній апроксимації. Результати обчислень наведено в табл. 2.

Таблиця 2. Математичний опис кривих сушіння гранульованих висівок

\begin{tabular}{|c|c|c|}
\hline Апроксимація & Рівняння & $\begin{array}{c}\text { Достовірність } \\
\text { апроксимації, } R^{2}\end{array}$ \\
\hline 1 & 2 & 3 \\
\hline \multicolumn{2}{|c|}{$1 . d=7,7 \mathrm{Mm}, t=10^{\circ} \mathrm{C}$} & 0,7076 \\
\hline Лінійна & $y=-0,2814 x+19,36(5)$ & 0,8895 \\
\hline Логарифмічна & $y=-0,8909 \operatorname{Ln}(x)+19,352(6)$ & 0,9788 \\
\hline Поліноміальна & $y=-0,0472 x^{3}+0,5976 x^{2}-2,4909 x+21,5(7)$ & 0,8958 \\
\hline Степенева & $y=19,35 x^{-0,0476}(8)$ & 0,7170 \\
\hline Експоненціальна & $y=19,362 e^{-0,0151 x}(9)$ & 0,6745 \\
\hline \multicolumn{2}{|c|}{$2 . d=7,7 \mathrm{MM}, t=20^{\circ} \mathrm{C}$} & 0,8560 \\
\hline Лінійна & $y=-0,3 x+19,3(10)$ & \\
\hline Логарифмічна & $y=-0,9541 \operatorname{Ln}(x)+19,296(11)$ & \\
\hline
\end{tabular}




\begin{tabular}{|c|c|c|}
\hline \multicolumn{3}{|c|}{ Продовження табл.2 } \\
\hline 1 & 2 & 3 \\
\hline Поліноміальна & $y=-0,0648 x^{3}+0,7877 x^{2}-3,1046 x+21,933(12)$ & 0,9746 \\
\hline Степенева & $y=19,293 x^{-0,0512}(13)$ & 0,8625 \\
\hline Експоненціальна & $y=19,3 e^{-0,0161 x}(14)$ & 0,6844 \\
\hline \multicolumn{3}{|c|}{ 3. $d=9,7 \mathrm{MM}, t=10^{\circ} \mathrm{C}$} \\
\hline Лінійна & $y=-0,2614 x+19,373(15)$ & 0,7048 \\
\hline Логарифмічна & $y=-0,8251 \operatorname{Ln}(x)+19,363(16)$ & 0,8808 \\
\hline Поліноміальна & $y=-0,0477 x^{3}+0,5909 x^{2}-2,4043 x+21,417$ (17) & 0,9705 \\
\hline Степенева & $y=19,362 x^{-0,0439}(18)$ & 0,8865 \\
\hline Експоненціальна & $y=19,375 e^{-0,014 x}(19)$ & 0,7137 \\
\hline \multicolumn{3}{|c|}{ 4. $d=9,7 \mathrm{MM}, t=20^{\circ} \mathrm{C}$} \\
\hline Лінійна & $y=-0,2863 x+19,322(20)$ & 0,6807 \\
\hline Логарифмічна & $y=-0,9108 \operatorname{Ln}(x)+19,319(21)$ & 0,8644 \\
\hline Поліноміальна & $y=-0,0594 x^{3}+0,7281 x^{2}-2,8982 x+21,79(22)$ & 0,9808 \\
\hline Степенева & $y=19,316 x^{-0,0487}(23)$ & 0,8707 \\
\hline Експоненціальна & $y=19,323 e^{-0,0154 x}(24)$ & 0,6901 \\
\hline
\end{tabular}

Аналіз отриманих рівнянь (табл. 2) показав, що найбільша достовірність апроксимації на рівні 97,05-98,08\% спостерігається для поліноміальних функцій, логарифмічна та ступенева функції отримали середню достовірність апроксимації на рівні $85,60-89,58 \%$, а низька достовірність апроксимації на рівні 67,45-71,70\% характерна для лінійної й експоненціальної функцій.

Криві швидкості сушіння гранульованих пшеничних висівок при охолодженні залежно від зміни ї діаметра 3 7,7 до 9,7 мм та при температурі повітря 10 та $20^{\circ} \mathrm{C}$ показано на рис. 2 .

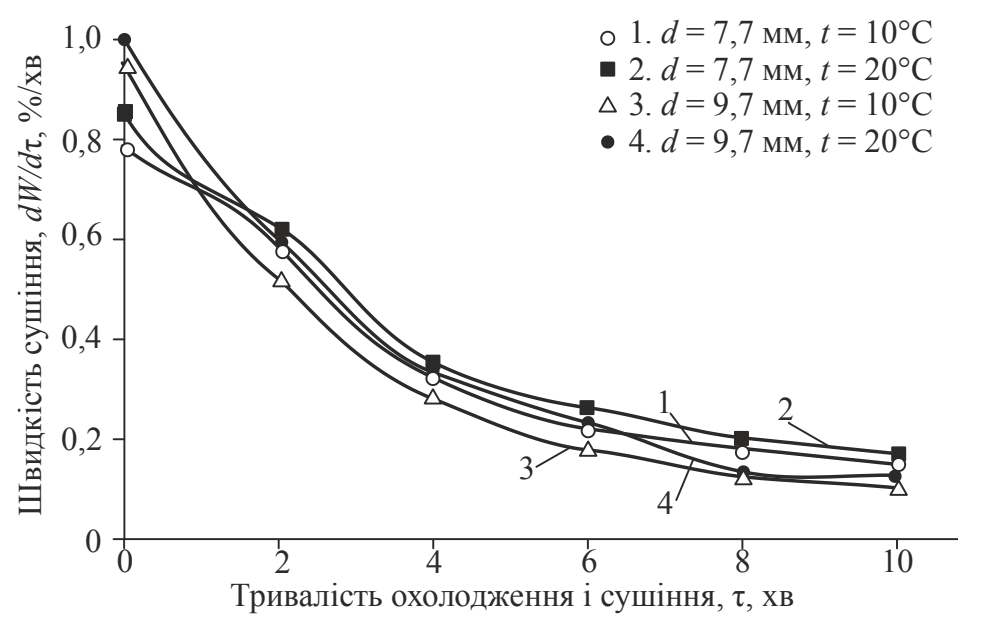

Рис. 2. Криві швидкості сушіння гранульованих пшеничних висівок при їх охолодженні $(V=0,6 \mathrm{~m} / \mathrm{c})$ 
За допомогою программного забезпечення для відповідних кривих швидкості сушіння висівкових гранул (рис. 2) були визначені рівняння, які відповідали різноступеневій поліноміальній апроксимації, оскільки вона мала найвищу достовірність апроксимації (табл. 2). Результати обчислень наведено в табл. 3.

Таблиџя 3. Математичний опис кривих швидкості сушіння гранул

\begin{tabular}{|c|c|c|}
\hline Степінь & Рівняння & $\begin{array}{c}\text { Достовірність } \\
\text { апроксимації, } R^{2}\end{array}$ \\
\hline \multicolumn{3}{|c|}{$d=7,7 \mathrm{MM}, t=10^{\circ} \mathrm{C}$} \\
\hline Другий & $y=0,0309 x^{2}-0,3434 x+1,105(25)$ & 0,9902 \\
\hline Третій & $y=0,0005 x^{3}+0,026 x^{2}-0,3287 x+1,0933$ & 0,9902 \\
\hline Четвертий & $\begin{array}{c}y=-0,0056 x^{4}+0,0792 x^{3}-0,3492 x^{2}+0,3688 x+0,6883 \\
(27)\end{array}$ & 0,9983 \\
\hline П’ятий & $\begin{array}{c}y=0,0031 x^{5}-0,0596 x^{4}+0,4321 x^{3}-1,4104 x^{2}+1,8048 x+0,01 \\
(28)\end{array}$ & 1 \\
\hline \multicolumn{3}{|c|}{$d=7,7 \mathrm{MM}, t=20^{\circ} \mathrm{C}$} \\
\hline Другий & $y=0,0329 x^{2}-0,3657 x+1,19$ & 0,9922 \\
\hline Третій & $y=-0,0009 x^{3}+0,0426 x^{2}-0,3951 x+1,2133(30)$ & 0,9923 \\
\hline Четвертий & 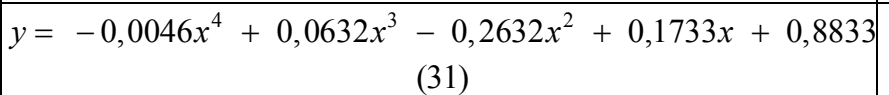 & 0,9971 \\
\hline П’ятий & $y=0,0043 x^{5}-0,0804 x^{4}+0,5592 x^{3}-1,7546 x^{2}+2,1915 x-0,07$ & 1 \\
\hline \multicolumn{3}{|c|}{$\mathrm{d}=9,7 \mathrm{MM}, t=10^{\circ} \mathrm{C}$} \\
\hline Другий & $y=0,0493 x^{2}-0,5027 x+1,372(33)$ & 0,9868 \\
\hline Третій & $y=-0,0104 x^{3}+0,1582 x^{2}-0,8315 x+1,6333(34)$ & 0,9999 \\
\hline Четвертий & $\begin{array}{c}y=0,0004 x^{4}-0,0162 x^{3}+0,186 x^{2}-0,8831 x+1,6633 \\
(35)\end{array}$ & 0,9999 \\
\hline П’ятий & $\begin{array}{c}y=0,0008 x^{5}-0,0142 x^{4}+0,0792 x^{3}-0,1008 x^{2}-0,495 x+1,48 \\
(36)\end{array}$ & 1 \\
\hline \multicolumn{3}{|c|}{$d=9,7 \mathrm{MM}, t=20^{\circ} \mathrm{C}$} \\
\hline Другий & $y=0,0479 x^{2}-0,5024 x+1,436(37)$ & 0,9940 \\
\hline Третій & $y=-0,0061 x^{3}+0,112 x^{2}-0,6962 x+1,59$ & 0,9982 \\
\hline Четвертий & $y=0,0012 x^{4}-0,0236 x^{3}+0,1954 x^{2}-0,8512 x+1,68$ & 0,9984 \\
\hline П’ятий & $\begin{array}{c}y=0,004 x^{5}-0,0687 x^{4}+0,4342 x^{3}-1,1812 x^{2}+1,0118 x+0,8 \\
(40)\end{array}$ & 1 \\
\hline
\end{tabular}

Аналіз результатів, наведених у табл. 3, дав можливість виявити декілька закономірностей. Було встановлено, що для гранул діаметром 7,7 мм поліноми в другому і третьому ступенях за достовірністю апроксимації $є$ ідентичними і лише для температури $20^{\circ} \mathrm{C}$ відрізняються всього на $0,01 \%$. Натомість для гранул діаметром 9,7 мм поліноми в третьому і четвертому ступенях за 
достовірністю апроксимації мали аналогічну спорідненість і лише для температури $20^{\circ} \mathrm{C}$ відрізняються всього на $0,02 \%$. Для всіх зразків найвищу достовірність апроксимації $R^{2}=1$ мали поліноми в п'ятому ступені.

Враховуючи, що на борошномельних заводах при гранулюванні висівок переважно не додають такі поживні компоненти, як меляса, жир, фосфатидний концентрат, то розрахунки щодо витрати теплової енергії на їх підготовку не проводили.

Прийняті параметри при визначенні витрат теплової енергії на гранулювання 1 тонни висівок: вологість висівок до преса гранулятора (14,0\%), температура висівок до пропарювання $t_{1}=20^{\circ} \mathrm{C}$, після пропарювання в змішувачі преса гранулятора $-t_{2}=60^{\circ} \mathrm{C}, \mathrm{K}_{\mathrm{T}}=1,2$ :

$$
\begin{gathered}
q_{\text {гр }}=1,2 \cdot(0,384+(0,616 \cdot 14 / 100)) \cdot(60-20)=1,2 \cdot 0,47 \cdot 40= \\
=22,57 \cdot 10^{3} \text { ккал } / \mathrm{T}=94,48 \text { МДж/т. }
\end{gathered}
$$

Прийняті параметри при визначенні витрати теплової енергії на підігрів зовнішнього повітря до $5^{\circ} \mathrm{C}$ при охолодженні 1 тонни гранульованих висівок: теплоємність повітря 0,31 ккал/( $\left.\mathrm{M}^{3} \cdot{ }^{\circ} \mathrm{C}\right), t_{\text {cер.o }}=-1,1^{\circ} \mathrm{C}$, витрати повітря на охолодження гранул $14400 \mathrm{~m}^{3} /$ год, продуктивність охолоджувача 8,5 т/год:

$$
q_{\mathrm{ox}}=0,31 \cdot(5-(-1,1)) \cdot 14400 / 8,5=3204 \cdot 10^{3} \text { ккал/т }=13414 \text { МДж/т. }
$$

Загальні витрати теплової енергії на гранулювання й охолодження 1 тонни висівок становитимуть:

$$
q_{3}=q_{\mathrm{rp}}+q_{\mathrm{ox}}=94,5+13414=13508,5 \text { МДж/т. }
$$

\section{Висновки}

1. За результатами визначення ТФХ гранульованих пшеничних висівок встановлено, що теплопровідність зростає при зміні вологості з 10,0 до 20,0\% від 0,862 до $1,304 \mathrm{BT} /($ м $\cdot К)$ за температури $20^{\circ} \mathrm{C}$ та від 1,016 до $1,676 \mathrm{BT} /($ м*К) за температури $60^{\circ} \mathrm{C}$; теплоємність — від 661 до 972 кДж/(кг'К) за температури $20^{\circ} \mathrm{C}$ та від 1215 до 1606 кДж/(кг К К) за температури $60^{\circ} \mathrm{C}$; а температуропровідність гранульованих пшеничних висівок знижується при зміні вологості з 10,0 до $20,0 \%$ з $20 \cdot 10^{-7}$ до $20,6 \cdot 10^{-7} \mathrm{~m}^{2} / \mathrm{c}$ за температури $20^{\circ} \mathrm{C}$ та від $12,9 \cdot 10^{-7}$ до $16,0 \cdot 10^{-7} \mathrm{~m}^{2} / \mathrm{c}$ за температури $60^{\circ} \mathrm{C}$.

2. Аналіз кривих сушіння (рис. 1) і швидкості сушіння гранул при їх охолоджені (рис. 2) свідчить про те, що процес зневоднення гранул відбувається у другому періоді сушіння при спадній ії швидкості. Зниження вологовмісту гранул при їх охолодженні протягом 10 хв при температурі повітря $10 \ldots 20^{\circ} \mathrm{C}$ і його швидкості $0,6 \mathrm{~m} / \mathrm{c}$ становить $0,6 \ldots 1,2 \%$, що не відповідає вимогам нормативних документів. Тому доцільним $\epsilon$ використання теплоносія 3 температурою $70 \ldots 80^{\circ} \mathrm{C}$ при сушінні гранул, виготовлених з використанням води як пластифікатора процесу гранулювання або гранулювати висівки 3 використанням пари тиском $0,2-0,3$ МПа 3 подальшим охолодженням гранул.

4. Найбільша достовірність апроксимації спостерігається для поліноміальних рівнянь, які описують як криві сушіння (97,05-98,08\%), так і криві 
швидкості сушіння. При підвищенні поліному до п’ятого ступеня розрахункова достовірність апроксимації становила $100 \%$.

3. Витрати теплової енергії на лінії гранулювання висівок мають значний розрив, оскільки на охолодження гранул після преса (13508,5 МДж/т гранул) витрачається майже в 143 рази більше теплової енергії порівняно з їх виготовленням (94,5 МДж/т гранул).

\section{Література}

1. Янюк T.I. Удосконалення технології преміксів з використанням пшеничних зародків : автореф. дис. ... канд. техн. наук : 05.18.02 / НУХТ. — Київ, 2002. — 19 с. [Електронний pecypc]. — Режим доступу : http://dspace.nuft.edu.ua/jspui/handle/123456789/7471.

2. Гинзбург А.C. Теплофизические характеристики пищевых продуктов [Текст] / А.С. Гинзбург, М.А. Громов, Г.И. Красовская. - Москва: Пищевая промышленность, 1980. $-288 \mathrm{c}$.

3. Соколенко A.I. Режимні способи інтенсифікації масообміну [Електронний ресурс] / А.І. Соколенко, О.Ю. Шевченко, О.С. Марценюк // Наукові праці Національного університету харчових технологій. - 2016. - Т. 22. — № 2. - С. 151-163. - Режим доступу : http://dspace.nuft.edu.ua/jspui/handle/123456789/23383.

4. Гапонюк I.I. Теплообмін двофазових середовищ за однакових градієнтів вологи й температури [Електронний ресурс] / I.I. Гапонюк // Харчова промисловість. - 2017. № 22. - С. 169-177. — Режим доступу: http://dspace.nuft.edu.ua/jspui/handle/1234567$89 / 26423$.

5. Лысенко Э.Н. Инструкция № 9-1-85 по нормированию расхода тепловой энергии на предприятиях мукомольно-крупяной и комбикормовой промышленности [Текст] / Э.Н. Лысенко, М.А. Мащенко. — Москва : ЦНИИТЭИ Минзага, 1985. — 72 с. 